\title{
A Nobel-díjas nemes Békésy György magyarságtudata
}

\section{The Hungarian Identity of the Nobel Prize Winner Georg von Békésy}

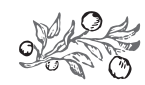

Összefoglalás

Nemes Békésy György orvosi Nobel-díjat kapott 1961-ben „a fül csigájában létrejövô ingerületek fizikai mechanizmusának felfedezéséért”. Tanulmányozván nemes Békésy György önéletrajza alapján megírt köteteket, megtaláltuk a „Békési-fészket” (maga Békésy nevezi így a kolozsvári házukat). A Békésy család ôsi tagjai erdélyi nemesek voltak. Dr. Békésy Sándor, Békésy György apja 1913. május 24-én kapta meg a nemesi címet, melyet kiterjesztettek a gyerekeire is. Az eredeti dokumentumok alapján elkészítettük nemes Békésy György családfáját, mely ily módon bekerült a szakirodalomba.

Kulcsszavak: nemes Békésy György, Nobel-díj, halláselmélet, családfa

Summary

Georg von Békésy was awarded the Nobel Prize in Physiology or Medicine "for his discoveries of the physical mechanisms of stimulation within the cochlea" in 1961. Consulting Georg von Békésy's own biographical book, it became clear that the "Békésy nest" (this term was used by Békésy himself for his family home) was in Kolozsvár (Cluj, today Romania). Several members of the Békésy family were noblemen. Nobility and the concomitant privileges were granted to Dr Sándor Békésy (the scientist's father) and his children on May 24, 1913. A detailed family tree and the genealogical details of Georg von Békésy have been compiled on the basis of historical documents and are presented for the first time ever in the literature.

Keywords: Georg von Békésy, Nobel Prize, audition, genealogy

Dr. VINCZE JÁNos biofizikus, nyugalmazott egyetemi tanár (ndp@t-online.hu). 
Polgári Szemle $\cdot$ 16. évfolyam 4-6. szám

\section{EsZMEFUTTATÁS AZ EGYES TÖRTÉNÉSZI MAgATARTÁSRÓL}

1945-tôl kezdôdôen hazánkban a szocialista szemléletú történészek összeültek - pártutasításnak engedelmeskedve -, és elkezdtek a múltról másképp nyilatkozni, meghamisítva ezzel a történelem egy-egy szeletét. Tették ezt olyan eredményesen, hogy esetenként csak akkor lehetett valamely régebbi esemény igazságát feltárni, ha felnőtt fejjel mindent elfelejtettünk, amit nekünk tanítottak, amit olvastunk, olvashattunk, és volt bátorságunk mindent megkérdőjelezni, és saját magunk utánakutatni a témának. Az alapvetô probléma, hogy a történészi ferdítések kihatottak és kihatnak még ma is az élet minden területére. Olyan területekre is, amelyek esetében már gyakorlatilag senkinek nem szembetûnô, mert megszokottá vált, és sajnos a beidegzôdés hatalmas úr. Egy ilyen terület a nevek írása.

\section{A MAgYAR NEVEK ÍRÁSA}

A magyar nevek helyes írására a Magyar Tudományos Akadémia által 1832 óta rendszeresen közreadott A magyar helyesírás szabályai az irányadó. A jelenleg érvényben lévô utolsó kiadás a tizenkettedik (2015). Fellapozva a kötetet, az Akadémia létrehozásában meghatározó szerepet személynél ezt olvashatjuk: „Széchenyi; Széchenyi István; elv.: Szé-che-nyi; széchenyies v. széchenyis; Széchenyi István-i; Széchenyi-díj; Széchenyi-díjas; Széchenyi-hegy, Széchenyi-hegyi; Széchenyi tér, Széchenyi téri.” Máshol: „Eötvös; Eötvös József és Loránd; eötvösi, Eötvös József-i és Loránd-i...” Bárki, aki csak egy kicsit is elgondolkodik a jól ismert, 19. századi magyar személyiségek nevein, rájön, hogy ók az életükben nem így írták a nevüket, hanem gróf Széchenyi István, báró Eötvös József. Vajon nekünk, utódaiknak van-e jogunk ezt megváltoztatni?

A magyar nevek írásába beleszólt a politika. A ma is hatályos 1947. évi IV. törvény rendelkezett egyes címek és rangok megszüntetésérôl.1 A szerzó személy szerint ezzel nem ért egyet, sốt a magyar családok sokasága sem, mert a temetôkben 1990 után igyekeztek a sírok fejtábláit módosítani. Jelenleg számos rendezvényen feltüntetnek egyes címeket és rangokat, sôt a bíróságokon hivatalosan bejegyzett vitézi szervezetek múködnek, melyek vitézi címeket adományoznak, és az adott személyek büszkén viselik azokat. Elfogadhatatlan az Alkotmánybíróság hivatalos indoklása is, hogy a rangok és címek használata az emberek származás szerinti megkülönböztetését vonná maga után.2 Ezt az álláspontot képviselte a szocialista társadalmi rendszer is.

Lássuk, hogyan állunk a dr. használatával. A szocializmusnak 1960-as éveiben a dr. használata tilos volt, az orvosi egyetemek az okleveleiken sem tüntethették fel. A jelenlegi szabályozások alapján az orvosi, a fogorvosi, a gyógyszerészeti, az állatorvosi és a jogi szakokat végzettek használhatják a dr. jelölést, és ezt a személyi igazolványukba is bevezethetik. A magyar nyelvi használatban akad egy lényeges zavar, mert a tudományos fokozatot is a köznyelvben doktorátusnak nevezik. A szerzó javasolta, hogy a tudományos fokozattal rendelkezók nagy Dr.-t írjanak, de ezt az Akadémia nem fogadta el. 


\section{Vincze János: A Nobel-díjas nemes Békésy György magyarságtudata}

\section{A MAGYAR ARISZTOKRÁGIA}

A magyar nemesség vagy magyar arisztokrácia feudális előjogokkal rendelkezô, uralkodó társadalmi osztály volt a Magyar Királyságban. Számuk az újkori magyar történelemtől folyamatosan nőtt, 1787-ben Magyarországon és az Erdélyi Nagyfejedelemségben több mint 400 ezer nemesi rangú személy élt. A kiegyezést követóen, a 19. századra az Osztrák-Magyar Monarchiában (azon belül is a Magyar Szent Korona országaiban) már 700-800 ezer fố számított valamely nemesi rétegból valónak (kis-, köz- és fónemes).

A magyar nemességen belül a 16. század második felétól rendszerezve létezik a fônemesi címek használata; Magyarországon fontossági sorrendben csak adományozták a bárói és grófi címeket, melyek közül az elsố alacsonyabb ranggal bír; a Magyar Király törvényei és szokásai szerint ezzel a két címmel az adományozott összes fia és leánya jogosult a használatára, valamint fiú gyermekeinek az egyenesági fiúági leszármazottjai is. Tehát egy grófi címmel rendelkezô asszonytól a fia vagy leánya nem örökölhette anyja címét, illetve nemességét sem, csak az apja rangját, illetve címét örökölte.

Az arisztokraták általában magas fokú múveltségre nevelték utódaikat, és nagyon gyakran vettek részt jótékonysági akciókban. Ennek egyik legtipikusabb példája az Akadémia megalakulása (gróf Széchenyi István kezdeményezésére); az akadémiai könyvtár létrejötte (gróf Teleki József adományából); az Erdélyi Múzeum létrejötte (gróf Mikó Imre adománya nyomán), a marosvásárhelyi Teleki-téka megalapozása (gróf Teleki Sámuel 40 ezer kötetbôl álló könyvtárából jött létre, ốt nagyban támogatta felesége, iktári Bethlen Zsuzsanna, aki sok könyvet örökölt nagynénjétől, báró Wesselényi Katától); Koronkán a templom és az iskola is gróf Toldalaghi Lajos birtokára épült, és az ô adományából jött létre. Felesége, gróf Béldi Zsuzsanna mindenben támogatta férjét.

Egész Nagy-Magyarország területén több tízezer arisztokrata családnak a hasonló adományaiból épültek templomok, iskolák, múzeumok, és egyéb egyletek múködhettek nagyon hasznosan a magyar nép javára. Amikor hazánkban még nem múködtek egyetemek, akkor magyar arisztokraták vagy az egyházak finanszírozták a tehetséges magyar fiatalok külföldi tanulmányútjait. Apáczai Csere János (1625-1659) püspöki ösztöndíjjal tanult öt évig Hollandiában. Ezen külföldön tanult magyar fiatalok számára természetes volt, hogy visszatértek hazájukba, mert adósságukat tevékenységükkel igyekeztek törleszteni az akkori magyar társadalom felé.

\section{A MAgYAR NEVEK ÁTÍRÁSA}

Itthonról kirívó példákat említhetünk, amikor egyesek, elsôsorban a politikai karrierjük érdekében, átírták a nevüket. Ilyen például Rosenfeld Mátyás (Rákosi Mátyás), ${ }^{3}$ Singer Ernô (Gerô Ernô), ${ }^{4}$ Lederer József (Révai József),${ }^{5}$ Lövy Hermann (Farkas Mihály), ${ }^{6}$ Löwinger György Bernát (Lukács György) ${ }^{7}$ Eisenberger Benjámin (Péter Gábor), ${ }^{8}$ Kohn Béla (Kun Béla). ${ }^{9}$ De egyéb okokból mások is átírták a vezetéknevüket: 
Schimert János (Szentágothai János), ${ }^{10}$ Reichenbach György (Romhányi György). ${ }^{11}$ Külön történet Semmelweis Ignác feleségének a névváltoztatásai. ${ }^{12}$

Az elmúlt évszázadokban nagyon sok értékes, nagy tudású magyar megfordult külföldön, és sokan közülük különbözô körülmények miatt végleg ott maradtak. A magyar nyelv nagyon specifikus írásmódja miatt számos probléma következett be a nevük írásánál. Ez elsôsorban abból adódott, hogy a többi nyelvben általában nem használatosak a hosszú magánhangzók, sốt számos nyelv esetén ezeknek az úgyszólván teljes hiányáról beszélhetünk. Elôször a keresztneveket írják át: Leslie (László), Charlie (Károly), Sophie (Zsófia), Johann (János), Nicolae (Miklós) stb. Majd gyakran a vezetéknevek is áldozatul esnek az átírásoknak: Dennis Gabor (Gábor Dénes), John George Kemeny (Kemény János), Cornelius Lanczos (Lánczos Kornél), Georg Andrew Olah (Oláh György), Leo Szilard (Szilárd Leo), Thomas Sebeok (Sebôk Tamás), Michael Curtis (Kertész Mihály), William Fox (Fried Vilmos), Georgina Hegedos (Hegedôs Györgyi). Crăciun Adalbert (Király Béla), Vinți Ştefan (Vincze István). Mikor ezen átírt nevek elôttünk feltúnnek, nemegyszer már képtelenek vagyunk azonosítani az általunk magyar névvel ismert személlyel.

\section{NeMes Békésy GyÖRgY Mit ÍRT Át A NEVÉBôl?}

Nemes Békésy György 1946-ben került végleg külföldre, és soha többé nem tért vissza Magyarországra. 1946-tól Svédországban töltött egy rövid esztendôt, majd az Egyesült Államokba ment dolgozni, és 1966-ban Honoluluban telepedett le, és ott is halt meg 1972-ben.

Mint általában a külföldre került magyar személyiségek, ô is átírta a keresztnevét Georgre (György helyett); a nemes elônevet „von”-ként használta, és a dolgozataiban is így tüntette föl magát. A vezetéknevét viszont továbbra is magyarosan használta, az é betúket ékezetekkel. Sokszor próbálták rávenni, hogy írja át a vezetéknevét, de ebból nem engedett. A Nobel-díjhoz tartozó oklevélen is a következóképpen tüntették fel a nevét: Georg von Békésy. Megtartotta a vezetékneve végén az ipszilont, melyrôl a külföldiek jó részének meg kellett tanulnia, hogy i-nek kell ejteni. Utolsó, önéletrajzi írása két évvel a halála után jelent meg (Annual Review of Physiology 1974. évi 36. kötetéból: Some Biophysical Experiments from Fifty Years ago. 1-18.), és ott is ily módon szerepel az aláírása.

A fenti elemzés alapján megállapítható, hogy Békésy többet megtartott a nevéból, mint általában azon magyar személyiségek, akik életük második felét külföldön töltötték. Békésy, ha magyarul írt, akkor pedig Békésy Györgyként használta a nevét.

\section{Milyen FiATALAB B KORI BENYOMÁSOK ÉRTÉK BÉKÉSYT?}

Édesapja, dr. Békésy Sándor Kolozsvárott született egy erdélyi nemes család sarjaként, és a Kolozsvári Egyetem tanára volt a századfordulón, majd diplomatapályára lépett. Édesanyja Mazaly Paula. A szülők Pécsett esküdtek meg 1898. augusztus 17 -én. ${ }^{13}$ Dr. Békésy Sándor az esküvô elôtt Bánfay S. pécsi királyi közjegyzô elôtt ún. reverzális fo- 
gadalmat tett. ${ }^{14}$ A pár legidôsebb gyermeke, György János József Budapesten született 1899. június 3-án, ${ }^{15}$ húga, Lola és öccse, Miklós azonban már Münchenben, miután a család követte az apát a magyar nagykövetségre. Jelen cikk szerzője többször külföldre utazott és elkészítette a nôtlen nemes Békésy György családfáját, az apai és anyai ôsöket feltüntetve.

\section{1. ábra: Békésy György családfája}

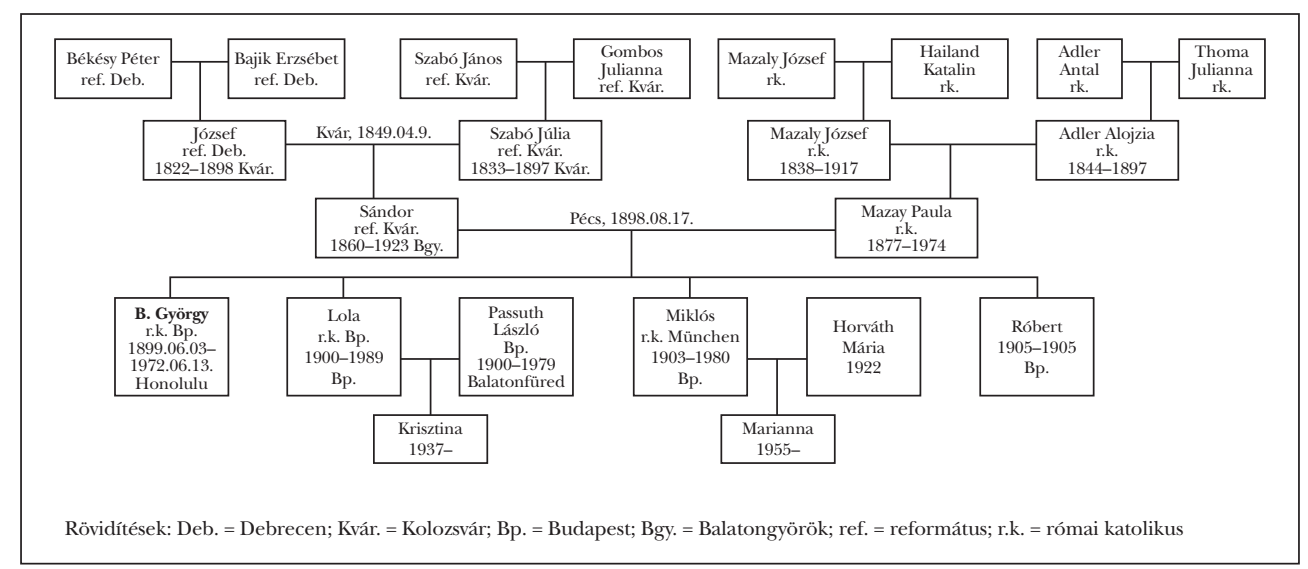

Forrás: Saját szerkesztés

A nemzetközi jogszabályok a nagykövetségek épületét Magyarországhoz tartozónak tekintik, és az ott dolgozók minden külföldi személlyel való találkozáskor a magyar államot képviselik. A négyéves György folyamatosan azt hallotta, hogy a családja, így ô is, tulajdonképpen Magyarországot képviselik külföldön. Egy apró gyerek ezt értelmileg még fel nem fogta, de érzelmi fejlódésében meghatározó tényezôvé vált. A nagykövetségen sok magyar múvész is megfordult. Rendszeresekké váltak a magyar nyelvú kulturális músorok, a kitúnố hallású gyermek szüntelenül hallotta a magyar népzenei elemeket, zenemúveket, népdalokat, látta táncolni a különbözô magyar régiókat képviselô magyar néptánccsoportokat. Ez a légkör mély nyomot hagyott a fiatal gyermekben, mely élete végéig meghatározó elemévé vált a személyiségének.

A diplomata édesapa változó munkahelyei színes, érdekes gyermekkort biztosítottak Békésy Györgynek, amelyre így emlékezett vissza: „Fiatal éveimben múvészek és más rendkívül érdekes emberek vettek körül. Apám sok barátot vonzott. Gondolatok, eszmék állandó cseréje mély benyomást hagyott bennem, ha nem is értettem mindent. Mégis öregkoromban arra emlékszem, hogy lehet kellemes és érdekes módon is élni. Az ilyen életet nem találjuk meg mindenütt, de akadnak ilyen helyek is, és nagymértékben a környezetünktôl függ"” (Békésy, 1974).

Nemességgel rendelkezett a Békésy család több tagja. Óriási öröm érte a családot, amikor a nemesség és elônévadományt a késôbbiekben kiterjesztették - 1913. május 24-én - dr. Békésy Sándorra és gyermekeire. Innentôl kezdve az édesapja a nagykövet- 
ségen minden találkozó alkalmával nemes Békésy Györgyként mutatta be a mindössze 14 éves fiút. Ez rangot adott, és tiszteletet vívott ki a társaságban. Akik ott megfordultak, hazaiak és külföldiek egyaránt, jól tudták, mit jelent erdélyi nemes család leszármazottjának lenni.

Íme, egy idézet arról, hogyan viszonyul Békésy - évtizedek múlva - Budapesthez: „Budapest története a rómaiaktól ível a modern idókig. Az elmúlt 2000 évben számos alkalommal lerombolták ezt a várost. De mindig ugyanazon a helyen építették fel újra. Sokszor kérdezték tólem, mi lehet az oka annak, hogy a magyarok, különösen a természettudományok területén, más népeknél sikeresebbek. Az a benyomásom, hogy az egy helyhez és egy célhoz történố ragaszkodás a fố oka annak, hogy hosszú fennállása alatt Magyarország jelentôsen hozzájárult ennek a világnak a kultúrájához" (Békésy, 1974).

\section{ISKOLAI TANULMÁNYOK}

Dr. Békésy Sándor diplomáciai küldetése folytán Münchenből Konstantinápolyba került, és így a fia 1910 és 1913 között a gimnázium alsó osztályait részben Konstantinápolyban végezte. De közben Pécsett járta ki a negyedik osztályt, és Budapesten az ötödiket. 1914 és 1916 között gimnáziumi tanulmányait a zürichi Minerva Intézetben letett érettségi vizsgával fejezte be, melyre így emlékszik vissza az önéletrajzában: „A svájci iskolák kitúnóek. Hálával tartozom apámnak, hogy azonnal felismerte, mennyivel jobbak a nyilvános iskolák a magánintézeteknél. Itt tanultam meg, milyen hatékony lehet a tanítás, ha azt helyesen csinálják olyan tanárok, akik valóban szeretik a hivatásukat. Ma is hálás vagyok svájci tanáraimnak. Egyszerú emberek voltak, de szerették a tanítványaikat. Svájcban három nyelvet beszéltek, franciát, németet és olaszt. Aki hosszabb ideig tartózkodott az országban, mind a hármat kisebb-nagyobb mértékben elsajátította. Én mindhármat a magyarral kevertem, így nem csoda, ha egyetlen nyelvet sem tudok tökéletesen. Svájcban le kellett tenni az érettségi vizsgát. A vizsga államilag ellenôrzött és nehéz. Miután sikerrel letettem, egy szabad fél év következett, mert felsőfokú tanulmányokat 18 éves kor elôtt nem lehet végezni” (Békésy, 1974). Ezt követóen múszerésztanonc lett Zürichben, ahol megtanulta a finom, precíziós munkát az órásmesterétôl. 1918 és 1921 között a Berni Egyetemen kémiaoklevelet szerzett.

\section{AZ ERDÉlyi ARISZTOKRATA KÖVETELMÉNYE}

Dr. nemes Békésy Sándor az egyetem elvégzése után azt mondta a fiának: „Egy erdélyi nemes a saját országában teszi le a doktorátust.” Nemes Békésy György pedig egyetértett édesapjával. Ez napjainkban elképzelhetetlen lenne. Békésy György édesapjának kérésére doktori értekezést készített a budapesti Tudományegyetemen Eötvös Loránd utódjánál, Tangl Károlynál: Folyadékok diffúziós állandójának meghatározása a Jamin-féle interferenciális refraktor segítségével” A dolgozatot magyarul és németül is publikálta. Békésy kísérleteinek végzésekor közvetve Eötvös tanítványává lett, ugyanis Eötvös egykori 


\section{Vincze János: A Nobel-díjas nemes Békésy György magyarságtudata}

laboránsa még ott dolgozott a tanszéken, és sokszor segített a fiatal kutatónak: „a kegyelmes úr nem így csinálná” - mondogatta gyakran. Békésy erre így emlékszik vissza önéletrajzában: „Néha igaza is volt. Ily módon tudtam meg, hogyan gondolkozik és hogyan dolgozik Eötvös, és ismét csak azt mondhatom, hogy egy probléma több különbözô oldalról való makacs megközelítésének egyszerúsége volt az, ami Eötvöst a világ kimagasló tudósainak egyikévé tette, függetlenül attól a ténytől, hogy Európa valóban nem kívánt elfogadni magyarországi tudósokat. Az angolok különösen lenézték a magyar tudóst. Hogy Angliába befogadjanak valakit, perfekt angolnak kell lennie, ma sem kell beszélnie az „amerikai angol” nyelvet, de beszélnie kell a „brit angol”-t (Békésy, 1974).

\section{Állami FELAdAT}

Egyetemi végzettséggel és doktorátussal, az elsố világháború után, Békésy nehezen kapott állást, végül a Budapesti Posta Kísérleti Állomásán helyezkedett el, gyakorlatilag laboránsként. (Emiatt 100 kutatóból legalább 99-nek kettétörik a pályáját, az idő elszalad a fejük fölött és kenyérkereset után kell nézzenek, családjuk lesz és a kutatói karrierük megsemmisül. De ez az elv nem érvényes az erdélyi nemes leszármazottra.)

Újra az önéletrajzból idézünk: „Magyarország nemzetközi távközlési központ volt, és a Prága-Belgrád-vonalon állandóan panaszok merültek fel, hogy Magyarország nem tartja rendben távközlô vonalait, és így Prága és Belgrád nem érti meg egymást. E panaszokat diplomáciai csatornákon közölték, már a magyar miniszterelnökhöz is eljutottak, ahonnan aztán jött lejjebb vég nélkül. Mivel látszólag nem volt megoldás, megkaptam a problémát. [...] A távbeszélő vonalak állapotának mérésénél mindig meg kellett mérni a vonal átvitelét hurokban, tiszta hangokkal. Ez gyakran órákig tartott, és ha elvégeztem a mérést, általában azt találtam, hogy ugyanazt a mérést megismételve a vonalak már változást szenvedtek. Egy olyan módszert kívántam kifejleszteni, mellyel a vonal vizsgálata néhány másodperc alatt elvégezhetố az egy óra hosszat tartó mérés helyett” (Békésy, 1974). A feladatot sikerrel megoldotta. Késóbb rájött, hogy a távbeszélô rendszeren belül a belsố fül sokkal jobb, mint a szokásos távbeszélố hallgató. Ezt a kutatási eredményét a Physikalische Zeitschriftben közölte, majd egyre több cikket közölt, mely nemzetközi sikert hozott. E sikerek révén mérnöknek nevezték ki, és kutatói csoportot hozott létre.

\section{BÉKÉSY HALLÁSELMÉLETE}

Röviden vázoljuk fel a Békésy által megteremtett halláselmélet legfontosabb megállapításait. Bebizonyította, hogy bárhonnan is érkezzék a hanginger (az ovális ablakon át vagy csontvezetéssel), az ovális ablaktól a csiga csúcsa felé haladó felületi hullámot hoz létre. A felületi hullám terjedési sebessége a membrana basilaris növekvô szélességétôl és lazaságától függ, és emiatt az ovális ablaktól távolodva egyre csökken (45 m/s-2 m/s).

A magas hangok keltette felületi haladóhullámok az ablakokhoz közeli keskeny, feszes részen, míg a mélyebb hangok okozta kilengések a távolabbi, kiszélesedett, laza 
végen keletkeznek. Mély hangoknál a hullámzás az egész membrana basilaris hosszát, míg magas hangoknál csak az elejét tölti ki. A membrana basilaris rezgései a Corti-szerv haladóhullámok által érintett szôrsejtjeit meghajlítják, így bennük elektromos potenciálkülönbség keletkezik. Az ingerelt szôrsejtekhez kapcsolódó hallóideg-végzôdések összegzik a fenti potenciálokat, és az inger erôsségétól függó ütemben akciós potenciálok sorozatát továbbítják az agyba. A hallás folyamatában a belsố szốrsejtek töltik be a hagyományos értelemben vett mechanoelektromos transzducer funkciót. Hanginger hatására a szốrkötegek megdólnek, a szôrsejtek membránjaiban potenciálváltozássá generálódik. Depolarizáló jellegú változás esetén a szinapszison keresztül kapcsolódó idegsejt akciós potenciáljának frekvencianövekedése következik be, ami az ingerületi állapotot jelenti. Békésy György korszakalkotó kísérleteire támaszkodó, új halláselméletét, a hangmagasság érzékelésének hely szerinti elkülönültségét 1928 és 1930 között közölte a Physikalische Zeitschrift folyóiratban.

A Posta Kísérleti Állomásán hallásvizsgáló készüléket tervezett. Ezt a készüléket „Békésy-féle audiométernek” nevezik, melyet még Magyarországon építette meg Pulvári Károly hangmérnökkel közösen. Olyan új elvet alkalmazott, amelyet más érzékszervek vizsgálatánál is használni lehetett. A Békésy-féle audiométert mind a mai napig használják a világon, a hallásvizsgáló intézetekben, az új betegek vizsgálatánál. A Békésy által készített eszköznek egy példányát megtalálhatjuk a Posta diósdi Rádióés Televíziómúzeumában. ${ }^{17}$

A nemzetközi elismerések nyomán az MTA - 1939-ben - levelezô tagjává választja. Ezt követôen a Pázmány Péter Tudományegyetem Kísérleti fizika tanszék vezetôje lett, ahol Eötvös és Tang utódjának tekinthetô. 1945-ben az MTA rendes tagja lett, de az egyetemen nem fogadták szívesen munkamódszereit. A laboratóriumait a háború alatt bombatalálat érte, és nem tudta folytatni az addigi kísérleti munkáját.

\section{Nemes Békésy György végleg elhagyja a haZÁJÁt}

Nemes Békésy György 1946-ban, miután a kísérleti laboratóriumát lebombázták, engedélyt kért a munkahelyétől, hogy Svédországba távozzon, a kísérleteit folytatni. Az engedélyt megkapva, a Karolinska Egyetemre ment. Az egyetemi laboratórium jóval kezdetlegesebb volt, mint Békésy volt budapesti laboratóriuma. A stockholmi laboratóriumot tovább kellett volna fejleszteni, de a háború miatt erre nem álltak megfelelő anyagiak a rendelkezésre. 1947-ben a Budapesti Tudományegyetem nem hosszabbította meg Békésy külföldi kutatói státuszát. Ezért engedett az újabb csábításnak, az Egyesült Államokba, Bostonba költözött, és a Harvard Egyetemen épített fel egy új, halláskutatásra szánt laboratóriumot. Itt kezdte tanulmányozni a fül csigájának elektromos folyamatait.

Amikor a szocializmus ideológiája vált uralkodóvá Magyarországon, a hazát elhagyó tudósokat, szakembereket fasisztáknak nevezték, megbélyegezték, gyalázkodó cikkek jelentek meg róluk, az egyetemi előadásokban negatív állításokat mondtak róluk, a könyvekben és a cikkekben nem lehetett idézni az eredményeiket. Ezen túlmenóen adminisztratív intézkedéseket hoztak: az egyetemek visszavonták az egyetemi tanári ki- 
nevezéseiket, és az MTA kizárta a tagjai közül. 1949-ben Rusznyák István ${ }^{18}$ elnökletével és Gerố Ernố ${ }^{19}$ maximális támogatásával, az akadémikusok egyötöde kizárta az akadémikusok négyötödét. A súlyos búncselekményt az Akadémia 1989-ben semmisítette meg, de ekkora a kizárt akadémikusok többsége már nem élt. Ezen eseményekrôl Békésynek is tudomása volt, mivel az édesanyja és testvérei Magyarországon éltek, és nem mert hazajönni attól tartva, hogy letartóztatják.

\section{1-BEN BÉKÉSY ORVOSI NOBEL-DÍJBAN RÉSZESÜL}

1961-ben nemes Békésy György orvosi Nobel-díjat kapott: „a fül csigájában létrejövő ingerületek fizikai mechanizmusának felfedezéséért”. Ezen kutatásait még Budapesten végezte, és a második világháború elótt publikálta is eredményeit. Tehát fontos kiemelni, hogy Békésy a magyarországi kutatásaiért kapta az orvosi Nobel-díjat. Nobel-beszédében is az előtte járó magyar szakemberekre hivatkozott. ${ }^{20}$

Bár nemes Békésy György 1947-től az Egyesült Államokban tartózkodott, az amerikai Magyar Nagykövetségen - fizetség ellenében - minden évben meghosszabbította a magyar állampolgárságát. Tehát nemes Békésy György magyar állampolgárként hunyt el 1972-ben az Egyesült Államokban. Békésy önéletrajzi írásában összehasonlítja a Horthy-rendszerben lévố magyar kutatási szabadságot az Egyesült Államokban tapasztalt kutatási lehetôségekkel: „A Harvard Egyetem nagyszerúen felszerelt pszichoakusztikai laboratóriumában 17 évet töltöttem. A laboratóriumot még a háborúban szervezték, szigorú szabályok szerint jó munkát végeztek. Késôbb sok más probléma merült fel, és túl sok vitára adott alkalmat. Az amerikai és magyar rendszer között nagy a különbség. Nekem az az érzésem, hogy a magyar rendszer ugyanazt a célt sokkal egyszerúbben éri el.

Az Egyesült Államokban az a szokás, hogy a problémákat mindig értekezleteken vitatják meg, és ezeken minden kérdés felmerül. Az ülések órák hosszat tartanak, a probléma legalább 5-10 embert érdekel, világos döntésre nem kerül sor. A magyar módszer kis laboratóriumokat foglalkoztatott. Mindenkinek megvolt a maga kis birodalma, azt tehetett, amit jónak látott. Kapott a kutatásra egy meghatározott részt a költségvetésbôl, és tovább nem kérdeztek semmit. Az Egyesült Államokban ez másképpen ment, az emberek a dollárért dolgoztak. Akadtak kivételek is, de nem ez volt a többség. Mindenkit a gyors eredmény érdekelt. Ilyen probléma Magyarországon nem merült fel, annyi ideig dolgozhattunk egy problémán, ameddig akartunk, fontos csak a jó, hibátlan eredmény volt.

Nem kérdés, hogy az Egyesült Államokban a laboratóriumok felszerelése sokkal jobb, mint Európában. A túl nagy felszerelés azonban még hátráltatja is az előrehaladást. Érzésem szerint, ha nincs felszerelés, akkor mindenki kénytelen ötleteit leegyszerúsíteni olyan módon, hogy a kísérletek egyszerúbbek legyenek. Ha túl sok felszerelés áll rendelkezésre, akkor egyszerre minden kísérletet elkezdenek, hiszen több pénzzel minden probléma megoldható. Végsố soron azonban a felszerelés annyira bonyolult lesz, hogy a részek együttmúködését nem lehet már áttekinteni. Visszatekintve a Magyarországon eltöltött idôre, gyakran az volt az érzésem, hogy tudományos munkám mélyebb és jelentôsebb volt, mint amelyet az Egyesült Államokban végeztem. 


\section{Polgári Szemle · 16. évfolyam 4-6. szám}

Az Egyesült Államokban végzett munkámat hamarabb elfogadták - így az utóbbi, szenzoros gátlással kapcsolatos kutatásaim elfogadása mindössze néhány évet vett igénybe -, míg Magyarországon végzett kutatásaimnak - annak ellenére, hogy a legtöbb országban jól ismerték azokat - sokkal hosszabb reakcióideje volt. Annak, hogy Magyarországon sikereket értem el, több oka volt. Elôször is, fiatalabb voltam, és nem aggasztottak az elóttem álló sikertelenségek, nehézségek. Másodszor, többet tudtam dolgozni, mint ma, és valószínúleg az is hozzájárult, hogy akkoriban az irodalom jóval egyszerúbb volt, mint manapság, amikor száz és száz cikket kell áttekintenem, mielôtt saját cikkemet leközölhetem. Harmadszor, a távközlési kutatólaboratórium szerencsére igen jól szervezett volt. Különbözô részlegekből - kábel, rádió, vegyészet - állt, egy épületben, és ha egy vegyészeti vagy egy nagyfrekvenciás problémám volt, nem okozott nehézséget, hogy azokat kollégáimmal megvitassam. Negyedszer, az Intézet mérete (akkoriban, úgy emlékszem, 95 fó dolgozott itt) olyan volt, hogy még lehetséges volt a kötetlen, fesztelen kapcsolat fenntartása minden erôszakolt kötetlenség nélkül is, mint ahogy ez ma sok esetben Európában vagy az Egyesült Államokban szokásos. Ötödször, valamennyi kollégám eléggé elfoglalt volt saját témakörében, de mégis tudott idôt szakítani arra, hogy különbözó kérdéseket velem megbeszéljen. Manapság az emberek nagy része túlságosan elfoglalt, és nem lehetséges többé olyan tudományos együttmúködés, amely annak idején könnyen kialakult. És végül, de nem utolsósorban a laboratórium igazgatója, Paskay Bernát és késôbb dr. Marschalkó Béla valójában nem olyan módon volt szervezó egyéniség, mint ahogy ma értik. A laboratórium kiválóan képviselt volt a magasabb szinten, védett volt az állami költségvetés problémáitól, így a szabad gondolkodásra és a szabad munkára elég szabadság volt. A keret, amelyból gazdálkodhatott, viszonylag alacsony volt a Magyarországon kívüli laboratóriumokéhoz képest, de egy előre meghatározott keret volt. Nem kellett idôt tölteni a támogatásért folyó harccal. Számítani lehetett rá, és ezért több idôt lehetett szánni arra, hogy egy kérdést hogyan oldjunk meg sikeresen. Néha rendkívül nehéznek találtam egy költségvetés elkészítését a következó 5 évre egy olyan felfedezéshez, melyet el akartam végezni. Az egyetlen dolog, amit tudtam a felfedezésról, az volt, hogy meg akarom valósítani, de nem tudtam, hogy hogyan, és a leghalványabb fogalmam sem volt róla, hogy mennyibe fog az kerülni. Ezért úgy éreztem, hogy olyan kijelentéseket kell tennem, amelyeket egyébként egyáltalán nem tettem volna. Késóbb, amikor a költségvetést jóváhagyták, arra kényszerültem, hogy olyan úton haladjak, melyet 3 vagy 4 évvel azelőtt terveztem, és ma már nem követtem volna (Békésy, 1974).

Békésynek a laboratóriumokkal nem volt szerencséje, mert a Harvard Egyetemen a laboratóriuma a túzvész martaléka lett 1966-ban. Ekkor határozta el, hogy elfogadja a Hawaiin múködô Honolulu-i Egyetem meghívását, ott a továbbiakban kutatásai az érzékszervekben létrejövô gátlásokra vonatkoztak, és teljesen új szemléletet vezetett be az érzékeléssel foglalkozó tudomány területén. Cikkeiból, előadásaiból E. G. Wever két könyvet állított össze: Experiments in Hearing (1960, Kísérletek a hallás területéről) és Sensory Inhibition (1967, Érzékszervi gátlás). 


\section{Vincze János: A Nobel-díjas nemes Békésy György magyarságtudata}

\section{BÉKÉSY VÉGRENDELETE}

Honoluluban 1970-ben írja meg a végrendeletét. ${ }^{21}$ Békésy kiváló érzékkel vásárolt igen értékes, eredeti ókori leleteket. Nagy szakértelemre tett szert a vizsgált kultúrákra vonatkozóan. Előfordult, hogy Gusztáv Adolf svéd királyt is meglepte széles körú, pontos tudásával. Régészeti, múvészettörténeti gyújteményét a Nobel Alapítványra hagyta. Békésy ezen múgyújteményéból megnyitott kiállításon a svéd király kijelentette, „ekkora értékú ajándékot a Nobel Alapítvány a Nobel-díjasoktól soha nem kapott”.

Itt újra ki kell emelnünk, hogy Békésy erdélyi nemes származású volt, így - mint az az arisztokrat a családokra jellemzô volt, hogy környezetüket nagy összegekkel támogatják - Békésy az ókori kultúrát mentette át a 20. és a 21. század emberisége számára.

\section{UTószó}

Jelen cikk szerzője Békésy múgyújteményét egy időszakos kiállítás idejére Stockholmból óhajtja Magyarországra hozatni, s ehhez a kéréshez a Nobel Alapítvány pozitívan viszonyult. Napjainkban ennek az idôszakos kiállításnak a megszervezése folyamatban van.

\section{JEGYZETEK}

1 A ma is hatályos 1947. évi IV. törvény egyes címek és rangok megszüntetésérôl a második világháborút követô magyarországi társadalmi változások egyik fontos dokumentuma. Ez az egyébként igen rövid törvény mondja ki az örökletes nemesi rangok és más címek, így a vitézi cím megszüntetését és használatuk tilalmát. A törvényt 1947. január 14-én hirdették ki, s attól a naptól hatályos. 1990 után számosan támadták a törvényt, amely kiállta a próbát, és hatályos maradt.

2 2009. szeptember 21-én az Alkotmánybíróság is visszautasított egy indítványt, amely a törvény 3. § (1)(4) bekezdéseinek, vagyis a címviselési tilalmak megsemmisítését kérte.

3 Rosenfeld Mátyás (Rákosi Mátyás), 1945 és 1956 között a Magyar Kommunista Párt elsố titkára.

4 Singer Ernố (Gerố Ernô), 1956-ban az MDP elsố titkára, szovjet NKVD-tiszt.

5 Lederer József (Révai József), a Rákosi-korszak meghatározó kultúrpolitikusa és ideológusa.

6 Lövy Hermann (Farkas Mihály), a Rákosi-korszakban honvédelmi miniszter.

7 Löwinger György Bernát (Lukács György), közoktatásügyi népbiztos; parancsot ad, hogy gyávaságért tizedeljék meg a románok elől meghátráló katonákat.

8 Eisenberger Benjámin (Péter Gábor), az Államvédelmi Hatóság vezetôje.

9 Kon Béla (Kun Béla), a Magyar Tanácsköztársaság vezetôje.

10 Schimert János (Szentágothai János), az MTA elnöke.

11 Reichenbach György (Romhányi György), orvos-patológus, akadémikus.

12 Semmelweis Ignác özvegye, Weidenhofer Mária családja és barátai rábeszélésére még a nevét is megmagyarosította Szemerényire. Jóval Semmelweis halála és a névmagyarosítás után két leányával együtt vissza akarta venni a Semmelweis nevet, de már nem lehetett. Hogy az akkor már felfedezett név ne haljon ki, kérték leányának, Lehoczkynénak két fia számára a dupla név, vagyis a Lehoczky-Semmelweis név használatát. Erre királyi engedélyt kaptak.

13 A Pécsi Székesegyház Római Katolikus Plébániájától megkaptuk a házassági levél másolatát. A házasságkötéskor a tanúk voltak Erreth János és Lösch István, az esketô plébános Károly Ignácz.

14 A reverzális fogadalom azt jelentette, hogy Dr. Békésy Sándor mint református hozzájárul, hogy a házasságából születendô gyermekeit katolikusnak kereszteljék. Ez a reverzális fogadalomtétel 1945-ig fennállt. 


\section{Polgári Szemle · 16. évfolyam 4-6. szám}

Majd az állami esküvố lett elsôdleges, és a katolikus egyház többé nem tudta fenntartani ezt a követelményt. Máskülönben nagyon sok családot veszített el emiatt a katolikus egyház.

15 A budapesti Római Katolikus Plébániától megkaptuk Békésy György születési bizonyítványának a másolatát.

16 Az Annual Review of Physiology 1974. évi 36. kötetéből. Nemes Békésy György önéletrajzi írása, mely halála után két évvel jelent meg 1974-ben, de 1972 március elején írta.

17 1995. január végén vetôdött fel a diósdi Rádió- és Televíziómúzeumban, hogy kérni kellene Hawaiiból Békésy György munkásságáról dokumentumokat. 1995. április végén érkezett a hír: a Békésy Múzeum teljes anyagát a Postai és Távközlési Múzeumi Alapítvány Rádió- és Televíziómúzeumának ajándékozzák, amennyiben a megajándékozott vállalja a csomagolás és Honolulu és Budapest között a szállítási költségeket. Az igazi közösségek ereje ilyenkor vizsgázik, hiszen erre anyagi fedezetük nem volt. A költségeket a Matáv Rt. amerikai vezérigazgató-helyettese, Ray E. Stewart úr biztosította, aki néhány éve bár, de már idetartozóként él közöttünk, hiszen nemcsak a távközlés jelenének és jövőjének gondjaival, de múltjának értékeivel is azonosult. A Békésy Múzeum anyaga 24 óriási ládában 1995. június 4-én érkezett meg washingtoni magyar követségünkre, onnan követségi konténerben folytatta útját, és 1995. július 13-án érkezett Budapestre. Ma két szobában vannak elhelyezve a Békésy-dokumentumok a diósdi Rádió- és Televíziómúzeumban.

18 Rusznyák István (1899-1974) zsidó származású, és Korányi Sándor kérésére Horthy Miklós 1931-ben kinevezte a szegedi belgyógyászati klinika élére. A 1944. március 19-i megszállás után a Gestapo deportálta Szegedrốl. Az akadémikus Baló József rögtön Budapestre utazott, és kihallgatást kért Horthy Miklós kormányzótól, aki rögtön intézkedett, és Rusznyák Istvánt leszedette a Németországba tartó vonatról. A késốbbiek folyamán Rusznyák Istvánnak és családjának nem esett bántódása. 1945-tôl kezdôdôen teljes mellszélességgel kiállt a kommunista párt és Rákosi Mátyás mellett, s így 1946-ban az MTA levelezô tagja és ugyanabban az évben rendes tagja lett. Rákosi Mátyás és Gerô Ernő támogatásával az MTA elnöke lett 1949-ben, és ekkor 41 tag támogatásával eltávolítottak az Akadémiából 163 tagot. Többek között azt a Baló Józsefet is, aki megmentette a deportálástól. De ekkor ebrudalják ki Békésy Györgyöt is. Rusznyák István 21 évig (1949-1970) volt az MTA elnöke, és ezalatt olyan súlyos kár érte a magyar tudományosságot, hogy azt mind a mai napig nem volt képes kiheverni. Az MTA elnöksége soha nem határolódott el Rusznyák István elvtelen döntéseitôl.

19 Gerô Ernô 1949 és 1957 között a Magyar Tudományos Akadémia (MTA) tagja, noha soha semmilyen felsôfokú tanulmánnyal nem rendelkezett.

20 Nobel-díjas beszéde részlete: „....az elsố otológiai díj kitüntetettje, Bárány Róbert (1876- 1936) (orvosi Nobel-díjas 1914-ben) ugyancsak magyar származású. Nem hiszem, hogy ez merô véletlen. Az otológia Magyarországon igen magas színvonalon áll, s valódi érdeklôdés övezi. Régóta gyanakodtam, hogy volt valamikor egy kiemelkedô személyiség, aki mindezt megalapozta. Sokáig hiába kerestem a kézikönyvekben, míg végül sikerült rábukkannom a nevére. Hôgyesnek (Hôgyes Endre, 1847-1906) alapította meg a Pasteur Intézetet és kórházat Magyarországon, a veszettség nemzetközi hírú kutatója volt, és 1901-ben orvosi Nobel-díjra jelölték) hívták..."

21 Végrendeletrészlet: 1. Kijelentem, hogy nőtlen vagyok. 2. Rendelkezem afelől, hogy a maradványaimat elhamvasszák, és a hamvaimat szétszórják. Amennyiben halálom nem Hawaiin ér, a hamvasztásra a legközelebbi erre alkalmas helyen kell sort keríteni, a maradványaimat pedig nem szükséges viszszajuttatni Honoluluba erre a célra. 3. Minden vagyonom fennmaradó részét, legyen az ingó, ingatlan vagy vegyes, függetlenül annak elhelyezkedésétôl és természetétôl, és minden olyan vagyont, amely felett rendelkezem akár kinevezési joggal, akár más módon, a Nobel Alapítvány (Sturegatan 14, Stockholm, Svédország) részére hagyományozom, mely szervezet készségét fejezte ki mútárgygyújteményem sértetlen megôrzését illetôleg. [...] 1970. október 12. napján, Honolulu városában, Hawaiin. Georg von Békésy. 


\section{Vincze János: A Nobel-díjas nemes Békésy György magyarságtudata}

\section{FELHASZNÁLT IRODALOM}

Békésy, Georg von (1928): Zur Theorie des Hörens. Die Schwingungsform der Basilarmembran. Physikalische Zeitschrift, Vol. 29, 781-793.

Békésy, Georg von (1929a): Zur Theorie des Hörens: Über die Bestimmung des einem reinen Tonempfinden entsprechenden Erregungsgebietes dér Basilarmembran vermittelst Ermüdungs- ercheinungen. Physikalische Zeitschrift, Vol. 30, 115-125.

Békésy, Georg von (1929b): Zur Theorie des Hörens: Über die eben merkbare Amplituden- und Frequenzánderung eines Zones: Theorie dér Schwebungen. Physikalische Zeitschrift, Vol. 30, 721-745.

Békésy, Georg von (1930a): Zur Theorie des Hörens: Über das Richtungshören bei einer Zeitdifferenz oder Lautstárkenungleicheit dér beiderseitigen Schalleinwirkungen. Physikalische Zeitschrift, Vol. 31, 824-835, 857-868.

Békésy, Georg von (1930b): Sur la théorie de l'audition. L'Année Psychologique, Vol. 31, 63-96.

Békésy György (1937): A hírközlés - akusztika. In: Posta mérnöki szolgálat 1887-1937. Stádium Sajtóvállalat, Budapest, 131-134.

Békésy, Georg (1960): Experiments in Hearing. McGraw-Hill Book Company, New York.

Békésy György (1964): A megfigyelés öröme és a belsố fül mechanizmusa. Orvosi Hetilap, 105. évf., 28. sz., 1325-1330.

Bekesy, Georg von (1967): Sensory Inhibition. Princeton University Press, Princeton.

Békésy, Georg von (1974): Some Biophysical Experiments from Fifty Years Ago. Annual Review of Physiology, Vol. 36, 1-18.

Békésy György (1978): Önéletrajzi jegyzetek. Fizikai Szemle, 28. évf., 8. sz., 281-289.

Dániel József (1990): Békésy György. Akadémiai Kiadó, Budapest.

Halm Tibor (1972): In memoriam Békésy György (1899-1972). Fül-orr-gégegyógyászat, 18. évf., 4. sz., 193-195.

Kovács Gergelyné (1995): A Békésy kiállítás története. In: Postai és Távközlési Múzeumi Alapítvány Évkönyve. Budapest, 38-67.

Kovács László (1999): Békésy György, az orvosi Nobel-díjas kísérleti fizikus. Savaria University Press, Szombathely. Nagy, Ferenc (ed.) (1999): The Nobel Foundation and Georg von Békésy. Better Kiadó, Budapest.

Passuth László (1977): A „nagy magányos”, aki megajándékozta a Nobel-intézetet. Magyar Nemzet, január 7. P.T. (1972): Békésy György. Élet és Tudomány, 27. évf., 27. sz., 1250-1254.

Radnai Gyula (1999): A megfigyelés öröme. Békésy György születésének 100. évfordulójára. Természet Világa, 130. évf., 6. sz., 263-265.

Tarnóczy Tamás (1962): Békésy György halláskutatásai. Fizikai Szemle, 12. évf., 7. sz., 197-206.

Vincze János (2018): A Nobel-díjas Békésy György családfája. Orvosi Hetilap, 159. évf., 4. sz., 156-158, https://doi.org/10.1556/650.2018.ho2583.

Vincze János (2019): Békésy György doktori disszertációja. Emlékezünk orvosainkra 47., NDP Kiadó, Budapest, $5-10$.

Vincze János (2019): A Nobel-díjas nemes Békésy György. NDP Kiadó, Budapest.

Vincze János - Vincze-Tiszay Gabriella (2019): Békésy György családja. Emlékezünk orvosainkra 48., NDP Kiadó, Budapest. 